\title{
Representation of Problems or Problematic Representation: Three Middle Eastern American Plays
}

\author{
Nazila Heidarzadegan ${ }^{1}[0$
}

*This article is prepared with reference to the phd dissertation titled "The Problem of Representation in Middle Eastern American Theatre: A Postcolonial Approach" which I completed in 2015 in the Atatürk University Institute of Social Sciences English Language and Literature Department.

'Assist. Prof. Dr. Karabuk University, Department of Western Languages and Literature, Karabuk, Turkey

\section{ORCID: N.H. 0000-0003-1238-7903}

Corresponding author/Sorumlu yazar: Nazila Heidarzadegan,

Karabuk University, Department of Western Languages and Literature, Karabuk, Turkey E-posta/E-mail: naziheidarzade@yahoo.com

Submitted/Başvuru: 04.03.2020 Revision Requested/Revizyon Talebi/: 20.04.2020

Last Revision Received/Son Revizyon: 08.05.2020

Accepted/Kabul: 17.05 .2020

\section{Citation/Atıf:}

Heidarzadegan, Nazila. "Representation of Problems or Problematic Representation: Three Middle Eastern American Plays" Tiyatro Eleştirmenliği ve Dramaturiji Bölümü Dergisi 30 (2020): 35-52

https://doi.org/10.26650/jtcd.698395

\begin{abstract}
Globally, several theatrical performances have staged the consequences of the 'war on terror' after $9 / 11$. This paper provides insights into how Middle Eastern American dramatists and characters responded to the war and the post-9/11 era. It explores how Middle Easterners in an American context were stereotyped, transformed into problematic subjects, how they resisted backlashing policies, and were influenced by fallout effects of the event in the plays Browntown, Ten Acrobats in an Amazing Leap of Faith, and Nine Parts of Desire by reading them through Homi Bhabha's postcolonial concepts. This paper argues for the necessity of recognizing hyphenated people in the mainstream context and approaches the problem in terms of negotiation instead of the negation of hyphenated identities to avoid potential identity problems which may lead to social problems. It calls for dramatists of artistic productions to claim recognition of their identity and correct the distorted images to prevent their transformation into problematic realms.
\end{abstract}

Keywords: Postcolonialism, Bhabha, Middle Eastern American Theatre, Representation, Problem 


\section{Introduction}

This study investigated the stereotyped images of Middle Eastern American characters written by Muslim American playwrights in Browntown ${ }^{1}$ by Sam Yunis, Nine Parts of Desire ${ }^{2}$ by Heather Raffo, and Ten Acrobats in an Amazing Leap of Faith ${ }^{3}$ by Yussef El Guindi by applying Homi Bhabha's postcolonial concepts borrowed from his seminal book The Location of Culture. The paper has detected stereotyped images of terrorists and Jihadists, along with backward, anti-Semite, polygamous, and misogynist images of Muslims which according to the authors are aimed to construct false global consciousness and create distorted images of Middle Eastern people. The purpose of this study was to scrutinize the problems of the Middle Eastern Americans in three plays. To discuss the stereotyped images of the hyphenated characters, the mentioned plays have been discussed in detail.

Nine Parts of Desire by Iraqi-American Heather Ruffo is about the stereotyped images of nine Muslim women performed by a single actor-director through monologues representing originary culture as an oppressing colonial agent. The veiled characters are in a world of their own, are untouchable and often misunderstood by outsiders at first glance, since they would judge them without attempting to unveil their world which is filled with the same human desires for peace, tranquility, equality, and life. They are not victims of the creeds of their religion but of hegemony, patriarchy, and imposed wars.

The women of the play are submissive and oppressed but they will not gain liberty by unveiling themselves. Their problem is not the unexposed body as a hidden locus of shame but the representation of it as a residue of the problem. While their indigenous local tradition has veiled them for protection in order not to be provocative, the liberating policies want to uncover them, claiming that they must possess their own body and expose it to be liberated. Both protection and provocation policies are phallocentric; one is conservative, the other revolutionary and resisting. The liberating policy, as a revolutionary act, supports it in local regions of the marginal but disapproves presentation and self-identification of veiled Muslim in émigré communities. These women's problem is not the veil, because veiled or unveiled, they are menaced by soldiers during an invasion as seen in Nine Parts of Desire when the teenage girl is not allowed to go to school since her family is afraid that she will be seduced by the soldiers. War and the unfulfilled desire for recognition by local men and global audiences are their problem, and reducing the problem to veil is naivety.

The second-generation members of the immigrant family of the Fawzis, who have been

1 Holly Hill and Dina Amin, Salaam, Peace: An Anthology of Middle Eastern-American Drama (1st ed.). (New York: Theatre Communications Group, 2009) 234-261.

2 Ibid., 112-166.

3 Ibid., 98-138. 
exposed to stereotyped images in Ten Acrobats in an Amazing Leap of Faith by Yussef El Guindi, the Egyptian-American dramatist, experience psychological conflicts and mental breakdown. The adherence to their roots, values, and religion is at once changed into the abhorrence of it, leading to the homosexuality of Hamza, atheism of Tawfiq, and schizophrenia of Huwaida. The hybridity of their culture as a hyphenated American, the uncanniness of either side while approaching the other half, miming one part to be the same even if not quite as the other, would leave them ambivalent and belonging to neither side, split, fragmented, and schizophrenic in a cultural and psychological sense. The desire of all these hyphenated American characters, especially Muslim Middle Eastern Americans, is the desire for recognition.

Browntown is a play about actors by Sam Younis, a Syrian Lebanese-American actorplaywright. Three Middle Eastern actors called 'Browntown people' audition for the role of an Arab in a "browntownship thing" (Holly Hill \& Amin, 2009)4. It is the role of a crazy Arab terrorist named Mohammed for a new television series. The movie industry was interested in Arab-American or Arab-American looking actors who are after making a living in this sector playing popular terrorist roles after 9/11. It represents stereotyped Muslims and Middle Eastern people as violent and scary, and the Arab in the movie audition scene is a valiant terrorist. Mohammad is the stereotyped name for terrorists, and Al Qaeda is a situated terrorist organization, therefore attributing any name to Al Qaeda is a sophisticated reason for making a community, the believers of a religion, or a name equal with Islam and Islam synonym with terrorism. Muslims and Arabs are stereotyped as misogynist and anti-Semite barbarians. Browntown is a play about stereotyped images of Muslims who are all represented as terrorists, anti-Semites, and polygamists who have four wives.

Browntown focuses on racism represented by Ann who is a director of movies on the Middle East, but she does not know that India is not an Arab state. Omar is shocked to learn that an Indian actor is playing Arab role.

Parry states that the Middle Eastern audience is "happy to hear their stories and seeing representations of people they recognize from their own lives and situations that they are familiar with" and does not force them "to leave them feeling isolated, marginalized or detested. They choose to attend the Middle Eastern theatre to laugh, relate, and feel like they were part of something and to be a part of that was an honor"s.

Browntown is a political play about the relationship between the Middle East and America after 9/11 and the 'War on Terror'. It investigates the cultural problems created by stereotyped images for three Middle Eastern actors at an audition for a film named The Color of Terror.

4 Ibid., 234-261.

5 Nigel Parry, The Perfect Antidote to the War on Terror. (2006). Retrieved from http://electronicintifada.net/ content/perfect-antidote-war-terror/5856. 
The play is filled with the Arab image as the Other. As El Guindi believes "there is no such creatures in natural world that corresponds to Muslim character. Stereotype is a bad joke with real world consequences" ". The sketches on Arab as the evildoer are clichés and prejudiced images widespread by the media. The play is about the question of misrepresentation and shows the interwoven relationship between images and reality attempting to defend Muslim identity criticizing the movies as unrepresentative and misrepresentation projects, and it intends to show how the Arab-American characters and writers should attempt to eradicate the negative images created by media and not allow their perpetuation in the public mind.

The Middle Eastern characters of the plays will remain unable to integrate if they are not recognized and respected for being half of one and not whole of the other. Recognition can be achieved through art as a medium, like what the characters of Ten Acrobats in an Amazing Leap of Faith did; Hamza plays the Oud, Tawfiq takes theatre classes, and Huwaida minors in drawing. Omar and Malek of Browntown act in movies, Layal, the alter ego of Raffo in Nine Parts of Desire is a leading artist. Also, the three authors who used theatre as a medium of awakening of the Middle Eastern Americans to present themselves and correct the distorted images profiling them, have used performance as a platform of negotiation of identity against negation of hyphenated identities.

The Fawzis of Ten Acrobats in an Amazing Leap of Faith, Omar and Malek of Browntown, and American Girl of Nine Parts of Desire, have moved from their native community to America and the cultural clash leads to plural anarchy because of moving from the general to specific sphere, not by "transition and transcendence, in new internationalism" . Émigré life is displacement, and the immigrant's culture is redefined, as said by Benedict Anderson, "it is not the process of politicians of alternative histories of the excluded or imagined community rooted in homogenous empty time of modernity producing a pluralist anarchy"s.

Hybrid moments in the lives of Huwaida, Tawfiq, Hamza, and Vijay are not a matter of "neither/nor but something else besides", since they are neither American nor Muslim, but unable to negate, resist, and signify their own identity in an Othering context, as Bhabha suggests, "the Other is cited, quoted, illuminated, and encased in the Other text. The Muslim Other loses its power to initiate its historic desire, and to establish its own institutional and appositional discourse" $"$.

6 Youssef El Guindi, Jihad Jones and the Kalashnikov Babes. (2008). Retrieved from http://www.asjournal. org/52-2008/the-theatre-of-yussef-el-guindi/.

7 Homi Bhabha, The Location of culture (London: Routledge, 1994), 5.

8 Benedict Anderson, Imagined Communities: Reflections on the Origin and Spread of Nationalism (London: Verso, 1983), 35.

9 Bhabha, The Location of Culture, 219.

10 Ibid., 46. 
The Iraqi women of Nine Parts of Desire are not members of Western civil society and the uncanny representation of them to American society defamiliarizes their accepted image. Cornell believes:

This reality of Muslim experience highlights how contemporary advocated Muslim identity politics have often made matters worse by accentuating symbolic tokens of difference between so-called Islamic and Western norms. Islam and Muslims are arguably all too visible because they are fundamentally different from the accepted norm. ${ }^{11}$

In three plays, cultural, moral, and religious values are part of a whole which is Islam. But, the original culture as the fixated source of truth for the displaced subjects faces enunciation, the process of experiencing fluctuating moments of belonging to neither/nor, either/or, and past and present. The Middle Eastern characters of the plays experience fragmented identity formed in the absence and presence of their past and present cultures. Huwaida, Hamza, Mona, and Tawfiq of Ten Acrobats, Omar, Malek, and Vijay of Browntown, and the American Girl of Nine Parts of Desire suffer from fragmented identity. They are:

split between the traditional cultural demand for a model, a tradition, a community, a stable system of reference, and the necessary negation of the certitude in the articulation of new cultural demands, meanings, strategies in the political present, as a practice of domination, or resistance. ${ }^{12}$

Cultural difference in Ten Acrobats in an Amazing Leap of Faith, Browntown, and Nine Parts of Desire makes the relation between the Self and the Other like the split subject destroyed by enunciation and "problematizes the binary division of past and present, tradition and modernity at the level of cultural representation and its authoritative address. Split subject of enunciation makes construction of identity ambivalent"13.

The characters of the three plays lose their sense of cultural and historical identity. The Middle Eastern culture as "a homogenizing, unifying force, authenticated by the originary past, is kept alive in the national tradition of the people"14 in Muslim communities in America. Being the Middle Eastern in America is disruptive. The hyphenated identity disrupts the purity and homogeneity of Americanness and "its hierarchical claims to inherent purity of cultures are untenable" $" 15$.

11 Vincent. J., Cornell, Voices of Islam: Voices of Art, Beauty, and Science (Vol. 4) (London: Praeger Publishers, 2007), xi.

12 Homi Bhabha, The Location of Culture (London: Routledge: 1994), 51.

13 Ibid., 35.

14 Ibid., 37.

15 Ibid., 37. 
It is that Third Space of enunciation between Muslim and American identity experienced by the characters of Ten Acrobats in an Amazing Leap of Faith, and Browntown and American Girl in Nine Parts of Desire, and the oppressive phallocentric rules cause Iraqi women to fluctuate between human, woman, and feminine identity; and un-representability of enunciating identity confirms oppression of originary culture against the dominant culture.

The authors write to resist positioning of backlash in the deepest resources of the American unconscious; while authentic visibility of the Middle Eastern Americans fade in the displacements of memory, art offers them the image of psychic survival. The Middle Eastern American authors's engagement with playwriting, Huwaida's drawing lessons, Tawfiq's drama classes, Hamza's Oud playing, Omar and Malek's role playing in movies, Layal's paintings and art in a general sense is a safety valve for all suppressed desires in the émigré psyche represented in the plays. The aim of the three plays is to affirm a solid position for the Middle Eastern Americans in works of art and to represent their problems in a new unwelcoming world via theatre.

The Muslim Other of the plays is not able to oppose the negating policy of the dominant discourse. The dark image of the Middle Eastern American distorts his presence and identifies him as an alienated subject. The alienation not only estranges his image as the American Other and the Muslim Self, but also presents the otherness of the Muslim Self as unhomely at any moment of confrontation with American identity.

The image of the Muslim Middle Eastern American has been identified with terrorism. For Bhabha this image reveals "incomplete representation of the colonized agent to split body and soul for refabricating identity" 16 and "to exist is to be called into being in relation to an otherness, its look or locus" $" 17$. Othering Muslim Middle Eastern characters of the three plays are calling them into existence and evoking the demand of finding their relation to Islam which constructs their identity and "identification is caught in the tension of demand and desire"18 . The fantasy of the Muslim Omar, Malek, Huwaida, and Raffo's women is precisely to be the American while keeping their Muslim identity safe. To be a Middle Eastern American is to be divided into two and to be at two places simultaneously, and it makes identification with the dominant culture impossible for the hyphenated colonized subject. Colonial desire is possession, homogeneity, and purity while the desire of colonized is recognition not exclusion, therefore, "the disturbing in-between distance constitutes the figure of colonial otherness as the white man's artifact inscribed on the religious identity"19.

16 Ibid., 44.

17 Ibid., 44.

18 Frantz Fanon, Black Skin, White Masks (New York: Grove Press Inc., 2008), xv.

19 Bhabha, The Location of Culture, 44. 
The identification of the Middle Eastern American characters for the psychologist, the director, and the audience of the plays resides in the affirmation of a stereotyped identity. They produce a distorted image and transform the Middle Eastern American to assume himself as the represented image. For Bhabha:

Identification is always the return of an image of identity that bears the mark of splitting the Other place from which it comes. The primary moments of such repetition of self lies in the desire of the look and the limits of language. The atmosphere of certain uncertainty certifies its existence and threatens its dismemberment. ${ }^{20}$

The stereotyped images represented of the Middle Eastern and Muslim people by the colonial agents in the plays are the exercise of colonial power through reducing a religion and its people to primitive people with backward moral standards, to being anti-Semitic, misogynist and with oppressed women, who have no free will. The worst of all is the terrorist stereotyped as a walking bomb. One possible way to have access to the true image of the Muslim Middle Eastern American identity hidden behind rag and veil is by resisting the stereotyped image as Raffo did. In Browntown and Ten Acrobats in an Amazing Leap of Faith, the second-generation immigrants like Huwaida, Omar and Malek attempt to access and present the true image of Islam through negating the stereotyped image of Islam by colonial authority and confront this image to form a boundary of otherness within their Muslim identity. The Muslim Other imagined by the American is opposed to the American self and "a fixed phenomenological point opposed to that represents a culturally alien consciousness. From that overwhelming emptiness of nausea in the colonial psyche, there is an unconscious disavowal of the negating, splitting moment of desire" ${ }^{21}$.

Hybrid identities of characters in Ten Acrobats in an Amazing Leap of Faith, Nine Parts of Desire, and Browntown reveal the struggle of identification and the war of position between the Self and the Other. Bhabha talks about the impossibility of representation of the Other by the collective will of hegemony and what the minorities represent is different from what is represented by power.

The hybrid immigrant family in Ten Acrobats in an Amazing Leap of Faith, especially Huwaida, lives beyond American mainstream culture and her atheist brother Tawfiq lives beyond familial, Islamic values and norms. Hamza, who is a normal character, is thrown beyond Islamic norms by a homosexual man and his gender identity becomes hybrid. The differences push them into 'beyond', "a transit where space and time produce the difference between past and present, inside and outside, inclusion and exclusion and the hybrid is born in 'beyond"' 22 .

20 Ibid., 117.

21 Ibid., 51.

22 Ibid., 1. 


\section{Homi Bhabha and Postcolonial Reading of The Plays}

Bhabha in many of his essays in The Location of Culture proposes new definitions of key postcolonial concepts, and it is worth summarizing the most influential of these here in analyzing the three dramas chosen from Salaam, Peace, An Introduction of Middle-Eastern American Drama, which are Browntown, Nine Parts of Desire, and Ten Acrobats in an Amazing Leap of Faith. Stereotype, hybridity, mimicry, ambivalence, Third Space, and colonial power have been selected from among other Bhabhaian concepts.

For Bhabha "people of hybrid identity are caught in the discontinuous time of translation and negotiation" $" 23$, and Muslim immigrant characters in Ten Acrobats in an Amazing Leap of Faith like Huwaida, Omar and Malek of Browntown, and the American Girl of Nine Parts of Desire struggle to create a safeguard against colonial culture in order to preserve the constancy of their primordial culture. The cultural and historical dimension of the Third Space of enunciation is a precondition for the articulation of cultural difference. Recognition of the international culture which is the split space of enunciation, should not be based on "the exoticism of multiculturalism or the diversity of culture" but on "the inscription and articulation of culture's hybridity", because "inter in international is the in-between space that carries the burden of the meaning of culture ${ }^{24}$.

Multi-ethnicity of American society does not provide enough Third Space for the Muslim community in enunciating moments, because "hybrid immigrant is transformed between truth and value, experiences displacement of time and person, and knows the defilement of culture and territory" and the stereotype of "native-migrant shifts between barbarism and civility, fear and desire and the colonial subject is over-determined and stereotyped from without". ${ }^{25}$

The Middle Eastern Americans in general, and Kamal's children in Ten Acrobats in an Amazing Leap of Faith, Omar and Malek of Browntown, and American Girl of Nine Parts of Desire in particular, have to comply with the stereotype model represented of them in order to exist and be recognized. However, miming the stereotyped American ideal model defamiliarizes and distances the Middle Eastern Americans from mainstream American ideals and is a failure in assimilating to whiteness. As Bhabha believes "mimicry can operate only as a melancholic process, as both a social and psychic malady". ${ }^{26}$

23 Ibid., 38.

24 Ibid., 38.

25 Ibid., 41-42.

26 Ibid., 61. 
Accepting 'the backward terrorist images as the dominant stereotype through which the Middle Eastern American people are identified in contemporary social domain, one learns that how mimicry functions as "a material practice in their racial melancholia" 27.

Bhabha's concept of mimicry is nearly a successful imitation in Mona's case in Ten Acrobats in an Amazing Leap of Faith. She accomplishes assimilating to American ideal model and fills the gap between Islamic and American identity. But failure in miming the mainstream culture results in psychological ambivalence that prevents Huwaida, Tawfiq, and Hamza from identifying with Western culture. Therefore, those Middle Eastern Americans who cannot adapt to the ideal model will suffer from depression and melancholia and will be excluded.

Huwaida and Hamza mourn the partial failure of identification and affiliation with original Middle Eastern culture. Thus, the Middle Eastern American characters of Ten Acrobats in an Amazing Leap of Faith, Browntown, and the American Girl of Nine Parts of Desire are ambivalent and mourn "the loss of whiteness as an ideal structuring of the assimilation and racialization processes" 28 and unavailability of Islamic culture.

The immigration experience for Kamal in Ten Acrobats in an Amazing Leap of Faith is accompanied with the mourning for loss of homeland and language which construct his identity. However, all immigrants are not melancholic or depressive, and Mona, Kamal's wife, and Vijay of Browntown are good examples of assimilated characters. The first-generation immigrants like Kamal, who evade assimilation and have not resolved mourning and loss, transfer melancholy but not hopes and dreams to the second-generation. However, unlike the intergenerational melancholy and depression, assimilation is not transferable, and the secondgeneration children of Kamal will not master their father's American Dream by assimilation, because inclusion and involvement in American culture and negotiation of dreams and hopes instead of mourning over the lost original identity are necessary.

The American audience of Nine Parts of Desire, the psychologist in Ten Acrobats in an Amazing Leap of Faith, and director in Browntown encounter the unhomed, alien Muslim characters whose presence make the non-Muslims uncomfortable. For Cornell:

To be unhomed is not to be homeless, but rather to escape easy assimilation or accommodation. There is no place to locate the unhomed in the majoritarian consciousness. Unhomeliness is a way of expressing social discomfort. ${ }^{29}$

27 David L. Eng and David Kazanjian, Loss: The Politics of Mourning (Berkeley: University of California Press, 2003), 53.

28 Ibid., 63.

29 Cornell, Voices of Islam: Voices of Art, Beauty, and Science, xi. 
For hybrid immigrant characters, "the unhomeliness provides "an ambivalent situation with paradoxical boundary between the private and the public sphere" ${ }^{30}$, the realms which for Hannah Arendt, "is uncanny because it is the distinction between things, that should be hidden and things that should be shown"31. The unhomely moments of immigration comes back as uncannily doubled problems, which "relates the traumatic ambivalence of psychic history to the wider disjunctions of political existence" ${ }^{\prime 2}$.

The colonial mimicry exercised by the psychologist in Ten Acrobats in an Amazing Leap of Faith, the director in Browntown, and the audience of Nine Parts of Desire leads to negation of the desire for a reformed, recognizable Muslim Other. Huwaida tries a swimsuit with veil in the nightmare which symbolizes her repressed desires; Tawfiq's atheism is an attempt to avoid his father's religion and be recognized as an American; Hamza's homosexuality and Vijay's indifference to his ethnic values are signs of Othering and articulating double by power. The characters' mimicry of American culture disturbs its authority because the civilizing mission is threatened by "the displacing gaze of its disciplinary double" 33 .

Stereotyping Muslims as barbarians and their religion as violent has created Islamophobia which is a global issue and displays Huwaida's inner self. Her double is the eruption of double suppression of her halves: her Muslim and American self, which return to live side by side. Bhabha explains this state as follows:

Stereotyping of an ethnicity makes the aborigines of that community hybrid, ambivalent, and enunciating between the mainstream established norms and native culture, turning the host culture into unheimlich for the migrant, and, émigré's culture as unheimlich for the host ${ }^{34}$.

Ashcroft et al. write, "ambivalence is embedded in the term diaspora" within which "the diasporic subject looks in two directions towards a historical-cultural identity on one hand, and the society of relocation on the other" ${ }^{35}$. For a diasporic subject, the hybrid and dual characteristics are most often associated with postcolonial discourse. In Browntown, Ten Acrobats in an Amazing Leap of Faith, and Nine Parts of Desire, the diasporic characters along with their authors are lost between a dual ontology at loss to choose either direction of racial and religious roots, because Islam is an inseparable part of their identity, in any society within which they are located, relocated, or even dislocated.

30 Bhabha, The Location of Culture, 22.

31 Hannah Arendt, The Human Condition, (Chicago: University of Chicago Press, 2013), 72.

32 Bhabha, The Location of Culture, 11.

33 Ibid., 86.

34 Ibid., 18.

35 Bill Ashcroft, Gareth Griffiths, Helen Tiffin, The Post-Colonial Studies Reader (2nd ed.) (London: Routledge, 2006), 435. 
The colonial mimicry exercised by the psychologist in Ten Acrobats in an Amazing Leap of Faith, the director in Browntown, and the audience of Nine Parts of Desire is doomed to failure because "the desire for a reformed, recognizable Muslim Other, as a subject of a difference" 36 .

Failure of mimicry for the Middle Eastern characters of the plays is the result of melancholia in the psychic domain of colonizers. This psychic discomfort forces diasporic subjects, mainly women characters of the plays, to be doubly dislocated and fluctuate between their histories, memories, and an ambivalent past, and uncertain future.

Desire in Nine Parts of Desire is Muslim women's life force sent to exile but revisited by the Iraqi-American author to reclaim her father's authenticity; she fights in her father's name to represent the true image by destructing the stereotyped and distorted image of Muslim women. The desire in Nine Parts of Desire is the women's unfulfilled desire to be recognized first by men of their community by avoiding patriarchal and phallocentric objectification to relegate them to body, and the desire to be recognized by others by not seeing them as veiled objects of sexual desire but by looking behind the veil; the desire behind the veil is not to be unveiled, as Western white feminists want to liberate them from, but to stop exploiting, invading, and stereotyping them as veiled and wild. The desire behind the veil is a universal womanly desire for peace, tranquility, safety, and desire for recognition both locally and globally. Desire for recognition is the desire of the nine women in Nine Parts of Desire which symbolizes every woman. Such female subjects may not easily find a language to speak therefore Raffo constantly spins and weaves Iraqi stories, legends, and myths into the warp and woof of new fabric of American culture and history to represent them.

Mahmood maintains that "veiling is a necessary component of modesty" 37 , in other words, "the veil is not an outward expression of interior feelings of modesty but a means of cultivating modesty and a disciplinary process that instills modesty. These reversals in exteriority/interiority contest normative liberal understanding of resistance shows that pious women's desire for veiling is shaped" 38 . Huwaida's subjectivity is formed through the resistance against liberal perception of veiling as an oppressing apparatus. Her insistence on veiling is not because of piety and modesty but resistance. The mission of liberating Muslim woman from her selfidentification as Muslim is by cultivating the veil as an oppressing apparatus by colonial mentality of the psychologist.

36 Bhabha, The Location of Culture, 86.

37 Saba Mahmood, Politics of Piety: The Islamic Revival and the Feminist Subject (Princeton, N.J.: Princeton University Press, 2005), 199.

38 Sherine Hafez, An Islam of Her Own: Reconsidering Religion and Secularism in Women's Islamic Movements (New York: New York University Press, 2011), 21. 
Huwaida's Islamist responses to American notions of progress is using the veil not only as a marker of the Islamization of public sphere, but also as an assertion of her public sphere. Her desire for veiling lies in the center of ambivalence, contradiction, and heterogeneity in discourses of modernity. Consequently, her subjecthood can never be truly captured as a single subject position in which her Self undergoes a consistent and uniform journey of self-fashioning. Her desire for veiling is an important point of departure for capturing subjectivity in its intensity and acts as a driving force creating the impetus for its very being. The geographies of desire underlie subject formation in women's Islamic activism.

Migrated but unable to be integrated is the main identity problem of the immigrant Egyptian family in the U.S in Ten Acrobats in an Amazing Leap of Faith. They confront problems of integration in a new context. Finally their identity is neither original nor identical. In Nine Parts of Desire the American Girl as the alter ego of Raffo had the chance to know her fatherland, but she was shocked seeing the incompatible image of Iraqi women represented on TV with the real life Iraqis. In Nine Parts of Desire Islam is not women's problem but Islamic rules, values, and traditions seem to be problematic for the American audience.

In Browntown, all three actors, Omar, Malik, and Vijay are American born Middle Easterners, who are asked which country they are from originally, when they say their State of residence. The hyphenated characters of Browntown are not accepted as American and in the audition, they have the chance to experience the attitude of American media towards the Middle Eastern Americans, at first hand. Multiculturalism as a problem and controversies involving cultural differences like veiling, Sharia, honor violence, misogyny and polygamy in Islam have been widely debated by policy-makers and the media as staged in Browntown, and are barriers against integration of Muslim Middle Eastern people into American society.

\section{CONCLUSION}

Since Orientalism focuses on the ways in which the Middle East has been represented in the West, to separate them, confirming Western superiority and negatively portraying and stereotyping East as the other, the distorted image disintegrates the Middle Eastern identity from Western society. John L. Esposito states that:

Despite diversity, the most obvious thread which exists in Muslim communities is Islam, not only as a faith but also as a source of identity and an important factor in social relations and politics and Islamic identity, ethnic identity, social characteristics, and other indigenous religious and cultural factors can explain the commonalities between Muslims. ${ }^{39}$

39 John. L. Esposito, The Oxford History of Islam (Oxford: Oxford University Press, 1999), 551. 
However, any attempt to separate Muslims from their 'original' culture and to engage them in the white Western culture is problematic. Malek and Omar are not detached from their original culture in Browntown. In Nine Parts of Desire the American Girl who was brought up in America, knows her fatherland and loves it, and in Ten Acrobats in an Amazing Leap of Faith, Tawfiq and Huwaida, intentionally, and Hamza unintentionally, endeavor to resist against their primordial culture which transfers them into problematic sphere.

The three plays stage colonial concerns about loss of racial purity and white culture which represent Middle Eastern people as a threat to homogeneous Western culture because:

a significant demographic shift that posits a major cultural challenge, the precise consequences of which are unpredictable and unforeseen that require a variety of adjustments by both the host countries and the new immigrants. ${ }^{40}$

Kamal of Ten Acrobats in an Amazing Leap of Faith who wishes to return to Egypt, excluded and repulsed Malek and Omar in Browntown, the Iraqi-American Girl in Nine Parts of Desire like many "Muslim immigrants, have become shrilled in declaring their presence a threat" They are reacting against the distorted image which increasingly depicts them as terrorists. In these plays, "colonial institutions as media and dominant culture cast doubt on Islam by propagating the superiority of its culture to separate Muslim from it" 42 .

The Islam in America can be defined as 'diasporic Islam' for second-generation migrants like Huwaida, Tawfiq, Hamza, Omar, Malek, and the American Girl. Consequently, one characteristic of Islam in diaspora is that "it approaches itself not as a religion, or not only as a religion, but as an identity which does not mean reducing religion to identity" ${ }^{43}$. Because of the contradiction in their identity, these characters feel unable to reconcile American and Islamic identities therefore society takes Islam not as an essential part of their identity but as a menacing factor to their social and psychological stability.

It is undeniable that after almost a millennium and a half from its emergence, "Islam retains an identity-shaping valence and transcends signifier of race, gender, class, and nationalism" 44 . 'Religion-based identity' is not exclusive to Islam; Judaism or Tibetan Buddhism are identifiers as well, but a person's voluntarily self-description as 'Muslim' becomes "a powerful identifier" that one chooses to adopt and "cannot be denied, rejected, or taken away by others" 45 .

40 Ibid., 601.

41 Ibid., 602.

42 Ibid., 283.

43 Mucahit Bilici, Finding Mecca in America: How Islam is Becoming an American Religion (Chicago University of Chicago Press, 2012), 70.

44 Amin Malak, Muslim Narratives and the Discourse of English (Albany: State University of New York Press, 2005$), 3$.

45 Bill Ashcroft, Gareth Griffiths, Helen Tiffin, Post-Colonialism: The Key Concepts (2nd ed.) (London: Routledge, 2007), 98 . 
Some of the claims about stereotyped images of women of the region have bases of truth in some Middle Eastern countries, but Muslim women are mostly known as "marginalized,

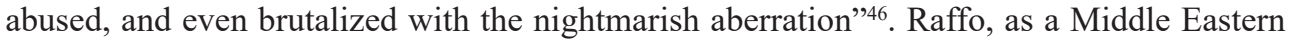
woman dramatist, writes sophisticatedly back to the colonial discourse and despite these deficiencies, she represents humane aspect of these women against objectified image of the Middle Eastern Muslim women depicted in the West.

The three plays object to anti-Islamism. The American audience of Nine Parts of Desire and the director in Browntown think Islam is anti-Western, however it is anti-colonial. The mission of three plays studied in this paper is to begin a dialogue between the Middle Eastern characters and authorial agents in plays as an opportunity for negotiating the Middle Eastern identity to enlighten both Western and Muslim audience and addressees, instead of negating Muslims' presence. For instance, Huwaida's pride in Islamic culture and her rejection of both patriarchal practices and Western hegemonic feminism renders her complex and challenging behavior as a reaction to disavowal policies. For James Clifford, the situation of diasporic people is as follows:

Diasporic communities, constituted by displacement, are sustained in hybrid historical conjunctures. With varying degrees of urgencies, they negotiate and resist the social realities of poverty, violence, policing, racism, and political and economic inequality. They articulate alternative public spheres, interpretive communities where critical alternatives both traditional and emergent can be expressed. ${ }^{47}$

The dialogue between Muslim and American characters of the plays, the audience, and the readers constitute the dialogue between Muslim and American mentality. Authors of the plays try to negotiate with American consciousness, mentality, and people through the dialogue between Muslim and American characters.

In Ten Acrobats in an Amazing Leap of Faith, Pauline the psychologist represents the culture which argues against hijab and Islam as a misogynist religion. In Browntown, the director symbolizes Islamophobia and the audience of Nine Parts of Desire are American people seated to listen to the women whom they want to liberate.

Trying to represent their differences, the characters of Ten Acrobats in an Amazing Leap of Faith and Browntown started "a complex, ongoing negotiation that seeks to authorize cultural hybridity that emerges in moments of historical formation" 48 . Cultural difference has produced the minority Muslim family of the Fawzis who are disintegrated because of marginality problems. Omar and Malek of Browntown are hybrid and split subjects within the

46 Malak, Muslim Narratives and the Discourse of English, 13.

47 James Clifford, Routes: Travel and Translation in the Late Twentieth Century (Cambridge, MA: Harvard University Press, 1997), 261.

48 Bhabha, The Location of Culture, 3. 
collective body of the nation. Social and cultural differences "are the signs of the emergence of minority community that takes the split subject 'beyond' itself to return in a spirit of revision and reconstruction of self in the present" ${ }^{\prime 49}$.

Huwaida who tries to represent her community feels intervention of the binary logic of Muslim and American self within in-between moments, and construct hybrid subject lost between the Self and the Other. Her loss of Islamic-Egyptian values forces her to mourn for dead values, leaving her depressed. The racial melancholia and depression of Huwaida, Tawfiq, Hamza, Omar, and Malek can avoid racial depression and melancholia by dissociating American values from Muslim Middle Eastern ones and segregating Islamic from liberal differences. Huwaida's depression and suspicion about her religious and American identity signifies "the torturous process of reinstatement that clearly impedes proper ego development". ${ }^{50}$ The inbetween space can prevent construction of identities of hybrid Huwaida, Hamza and Tawfiq, who are the second-generation migrants. Their in-between hybrid self exceeds the barrier of the present and goes 'beyond' what is known and presentable.

The imperialist production of knowledge about the Middle East and Islamic societies by the authority of the psychologist, the director, and the audience in the plays as perceivers, aims at representing the Middle East not as a community with its unique culture but as a repository of Western knowledge. The Middle East is represented as the inferior other of America in the plays that enables creation of a civilized and superior imperialist hegemonic power.

The problems of Muslim characters of the plays in American society will be forgotten by the third generations and all historical things will appear quite natural and unremarkable. For achieving this aim, scholarship on the Middle East in America needs to avoid taking the problems for granted.

The consequences of displacement and relocation of second-generation migrant characters are degeneration of identity and selfhood and oppression of their primordial culture by racial, ethnic, and religious ideal model of the host culture. Representatives of colonial power in the plays have to impel the colonizer's prejudiced stereotyped images accepted as truth, because the Middle Eastern culture is claimed to be irrational and its integration with Western logic would be impossible.

The Middle Eastern American theatre attempts to introduce Arab and the Middle Eastern view of culture, metaphysics, ethics, and aesthetics not as distinct and separate from universal values but different from it. Representing the difference as a misfit to homogeneous American culture leads to schizo culture and emphasizing it can force the hyphenated identities to feel

49 Ibid., 3

50 Jean Yuwen Shen Wu and Thomas Chen, Asian American Studies Now: a Critical Reader (New Brunswick, N.J.: Rutgers University Press, 2010), 71. 
disintegrated and excluded. The Middle Eastern people represented in Browntown, Nine Parts of Desire and Ten Acrobats in an Amazing Leap of Faith have been simplified into oppressed victims needing liberation and their religious, cultural, and traditional values are not replaced as being different but negated as Other.

Three plays, also, challenge the traditional white Western attitude associated with the liberation of women. The Middle Eastern women who are mostly Muslims have their own culture rooted in their religion and geographic characteristics of the region. They have different histories from white Western women and the limitations imposed on them by colonial conquests and invasions, besides the patriarchal and cultural rules have exposed them to these factors. Any attempt for liberation such as migration necessitates rewriting history with a new perspective for hyphenated identities since they develop different survival politics and experiences. There are some ideologies which aim to liberate the Middle Eastern women from patriarchal and religious oppression, but what is called oppression by white feminism is a cultural, religious, and regional value for majority of Muslim women and their families. Their objection to white feminism is the latter's representation of Muslim women as oppressed, silenced, and dominated waiting to be liberated, like the Iraqi women in Nine Parts of Desire, Mona and Huwaida in Ten Acrobats in an Amazing Leap of Faith, and Mohammed's misrepresented wives in Browntown.

These plays try to reject the predetermined stereotyped representation of the Middle Eastern people and try to decline the assumptions that the ideal model is white Western middle-class norms, because the Middle Eastern people have different problems and different solutions for them. Their worldview is different from each other, because they do not share common experiences based on oppression. Huwaida reacts against the psychologist who represents white feminism. The nine women react to American audience who symbolize Western people and Malek and Omar as men react against Western media's predetermined image of the East as an oppressed victim of religion and violent terrorism.

Not only are authors of three plays and the women in Nine Parts of Desire and Ten Acrobats in an Amazing Leap of Faith challenging ideologies which have belittled the status of the Middle Eastern people, but they also defy the dominant assumptions of supremacy of white Western culture in representation of hyphenated people as incongruous misfits in colonial discourse.

Nine Parts of Desire addresses the audience, Browntown discloses the Orientalists' view of filmmakers as the authority forming and directing global consciousness, and Ten Acrobats in an Amazing Leap of Faith represents the tragic identity loss within a migrated family in America as a consequence of profiling, excluding, and hyphenating as the Other. In the three plays, the West is shown to portray Eastern women "as the locus of Eastern backwardness" 51

51 Carole Ruth McCann, and Seung-Kyung Kim, Feminist theory reader: Local and global perspectives (London: Routledge, 2013) 221. 
and the Western discourse lies on Eastern women's public roles, marriages, domesticity, and their religion as victimizing factors.

This paper studied three plays investigating how the Middle Eastern people are represented in America. Nine Parts of Desire, Ten Acrobats in an Amazing Leap of Faith, and Browntown challenge assumptions about Muslims both in literature and society. Authors of the three plays criticized stereotyped and marginalized images of the Middle Eastern people by colonial authors and authorities who might claim to be challenging a culture of oppression. Othering will prevent integration of the Middle Eastern Americans into American society which may lead to various identity problems for the hyphenated people and social and cultural problems for the host culture. Art, particularly theatre, can negotiate identity problems with hegemonic culture to provide an opportunity of recognizing minority rights and termination of the exclusion and profiling policies.

Islam is presented as the identity forming factor superseding gender, race, and nationality for those identifying themselves primarily as Muslim. In order to reduce the problems arising from ignoring this fact which arises identity problem for Muslims and is menacing for the Western culture, the Middle Eastern people should try to negotiate with the host culture to assist recognition of it as an inseparable part of their Muslim identity. Probably, some Muslims cannot easily integrate into Western culture because of the difficulty of negotiating their identity, but negotiation is possible through theatre as a medium to communicate directly with people.

Peer-review: Externally peer-reviewed.

Conflict of Interest: The author has no conflict of interest to declare.

Grant Support: The author declared that this study has received no financial support.

Hakem Değerlendirmesi: Dış bağımsız.

Çıkar Çatışması: Yazar çıkar çatışması bildirmemiştir.

Finansal Destek: Yazar bu çalışma için finansal destek almadığını beyan etmiştir.

\section{BIBLIOGRAPHY}

Anderson, Benedict. Imagined Communities: Reflections on the Origin and Spread of Nationalism. London: Verso, 1983.

Arendt, Hannah. The Human Condition. Chicago: University of Chicago Press, 2013.

Ashcroft Bill, Griffiths Gareth, Tiffin Helen. The Empire Writes Back: Theory and Practice in Post-Colonial Literatures (2nd ed.). London: Routledge, 2002.

Ashcroft Bill, Griffiths Gareth, Tiffin Helen. The Post-Colonial Studies Reader (2nd ed.). London: Routledge, 2006. 
Ashcroft Bill, Griffiths Gareth, Tiffin Helen. Post-Colonialism: The Key Concepts (2nd ed.). London: Routledge, 2007.

Bhabha, Homi. The Location of Culture. London: Routledge, 1994.

Bilici, Mucahit. Finding Mecca in America: How Islam is Becoming an American Religion. Chicago University of Chicago Press, 2012.

Clifford, James. Routes: Travel and Translation in the Late Twentieth Century. Cambridge, MA: Harvard University Press, 1997.

Cornell, Vincent. J.. Voices of Islam: Voices of Art, Beauty, and Science (Vol. 4). London: Praeger Publishers, 2007.

El Guindi, Youssef. Jihad Jones and the Kalashnikov Babes. (2008). Retrieved from http://www.asjournal. org/52-2008/the-theatre-of-yussef-el-guindi/

Eng, David. L. and Kazanjian, David. Loss: The Politics of Mourning. Berkeley: University of California Press, 2003.

Esposito, John. L.. The Oxford History of Islam. Oxford: Oxford University Press, 1999.

Fanon, Frantz. Black Skin, White Masks (R. Philcox, Trans.). New York: Grove Press Inc., 2008.

Hafez, Sherine. An Islam of Her Own: Reconsidering Religion and Secularism in Women's Islamic Movements. New York: New York University Press, 2011.

Hill, Holly and Amin, Dina. Salaam. Peace: An Anthology of Middle Eastern-American Drama (1st ed.). New York: Theatre Communications Group, 2009.

Mahmood, Saba. Politics of Piety: The Islamic Revival and the Feminist Subject. Princeton, N.J.: Princeton University Press, 2005.

Malak, Amin. Muslim Narratives and the Discourse of English. Albany: State University of New York Press, 2005.

McCann, Carole Ruth and Kim, Seung-Kyung. Feminist theory reader: Local and global perspectives. London: Routledge, 2013.

Parry, Nigel. The Perfect Antidote to the War on Terror. (2006). Retrieved from http://electronicintifada.net/ content/perfect-antidote-war-terror/5856

Raffo, Heather. Heather Raffo's 9 Parts of Desire. New York: Dramatists Play Service, Inc., 2006.

Wu, Jean Yuwen Shen and Chen, Thomas. Asian American Studies Now: A Critical Reader.

New Brunswick, N.J.: Rutgers University Press, 